\title{
Chemical characterization of submicron regional background aerosols in the western Mediterranean using an Aerosol Chemical Speciation Monitor
}

\section{C. Minguillón et al.}

Correspondence to: M. C. Minguillón (mariacruz.minguillon@idaea.csic.es)

The copyright of individual parts of the supplement might differ from the CC-BY 3.0 licence. 


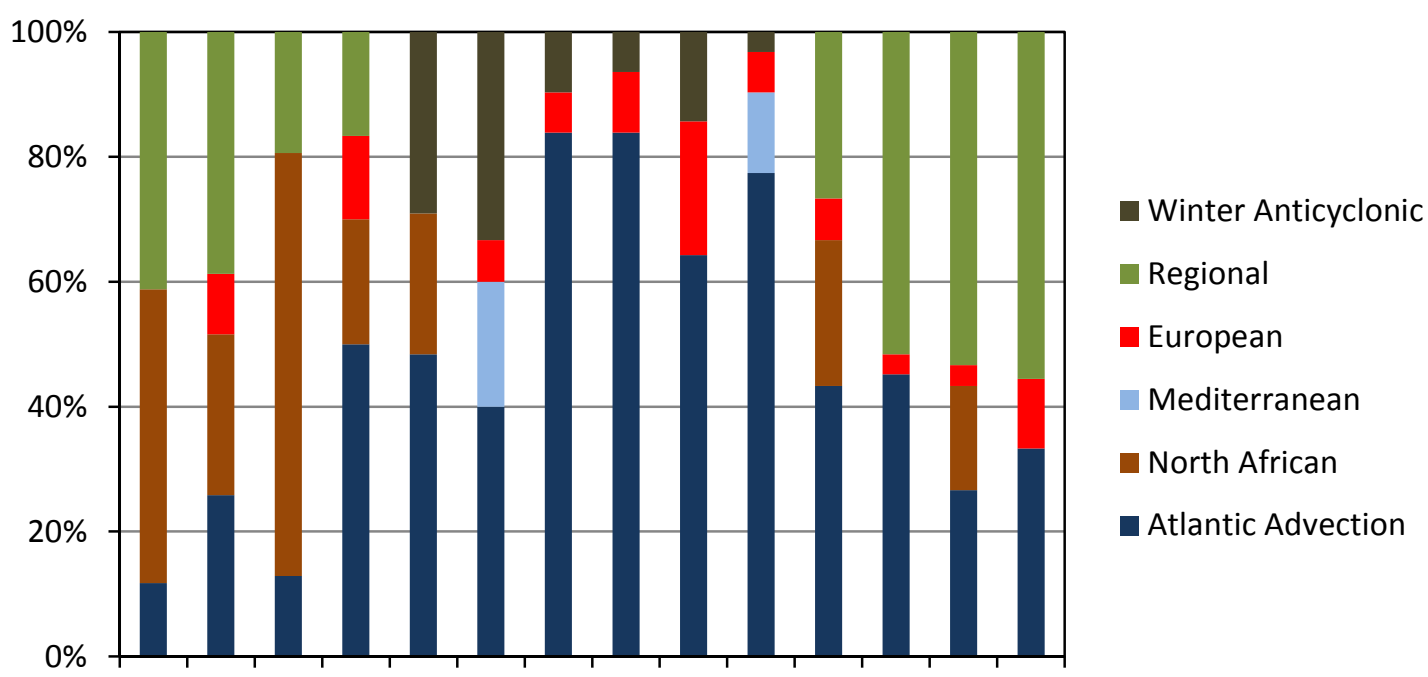

Jun Jul Aug Sep Oct Nov Dec Jan Feb Mar Apr May Jun Jul

Figure S1. Frequency of type of scenario for each of the months of the study period.
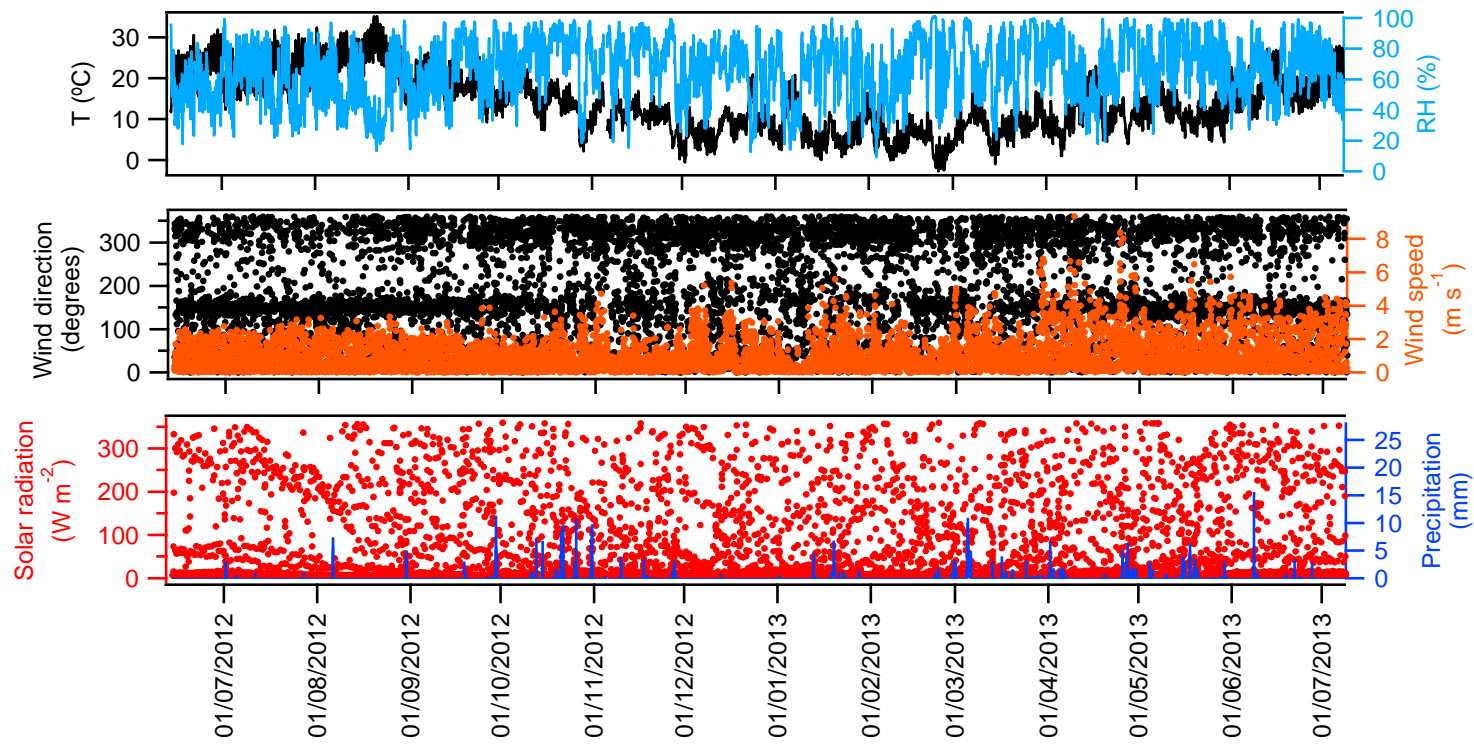

Figure S2. Hourly ambient temperature, relative humidity, wind direction and speed, solar radiation and precipitation at MSY during the study period. Date format dd/mm/yyyy. 


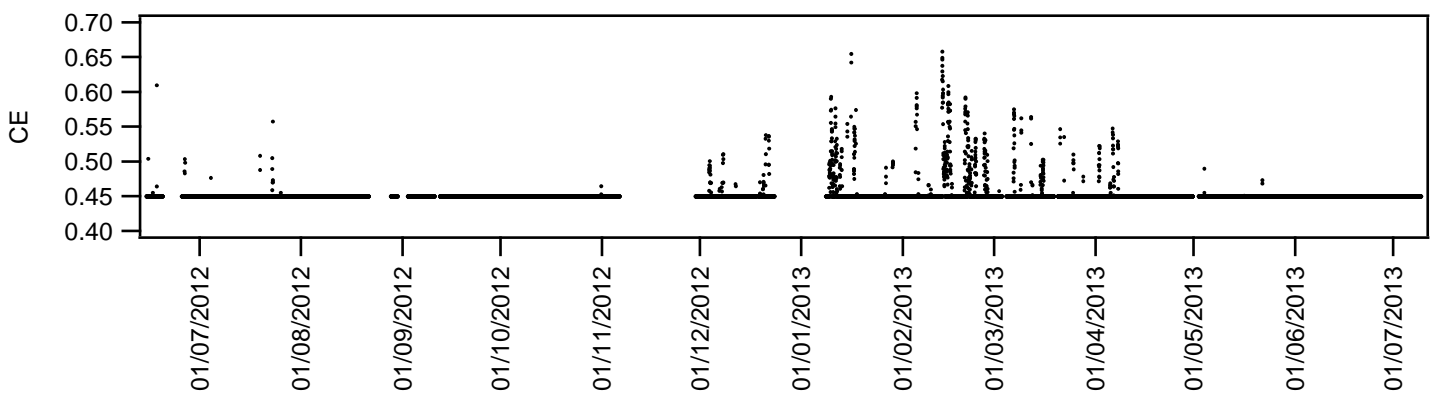

Figure S3. Time-dependent CE calculated with the Middlebrook approach (Middlebrook et al., 2012). Date format dd/mm/yyyy.

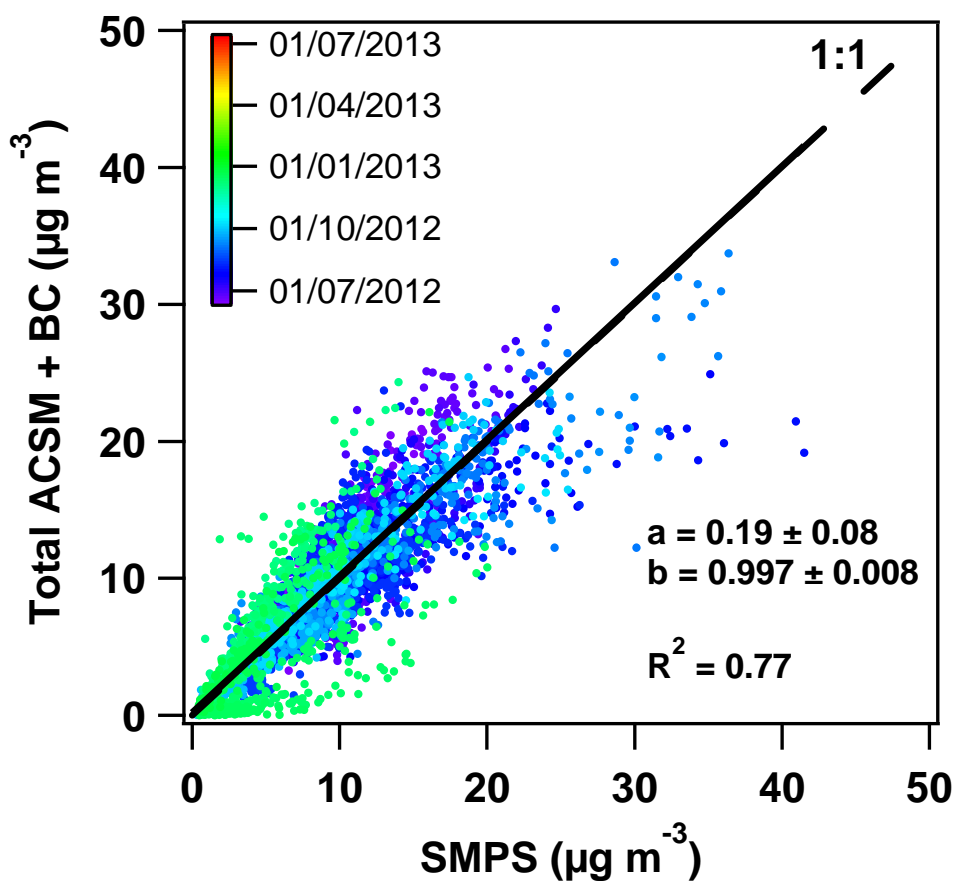

Figure S4. ACSM components + BC concentrations vs mass concentration calculated from Scanning Mobility Particle Sizer (SMPS) data coloured by the sampling time (dd/mm/yyyy). Data availability for SMPS data covered only $\mathbf{2 0 1 2}$ period. Line and parameters correspond to least orthogonal distance fit $(y=a+b x)$. The wild fire period is excluded from the fit. 


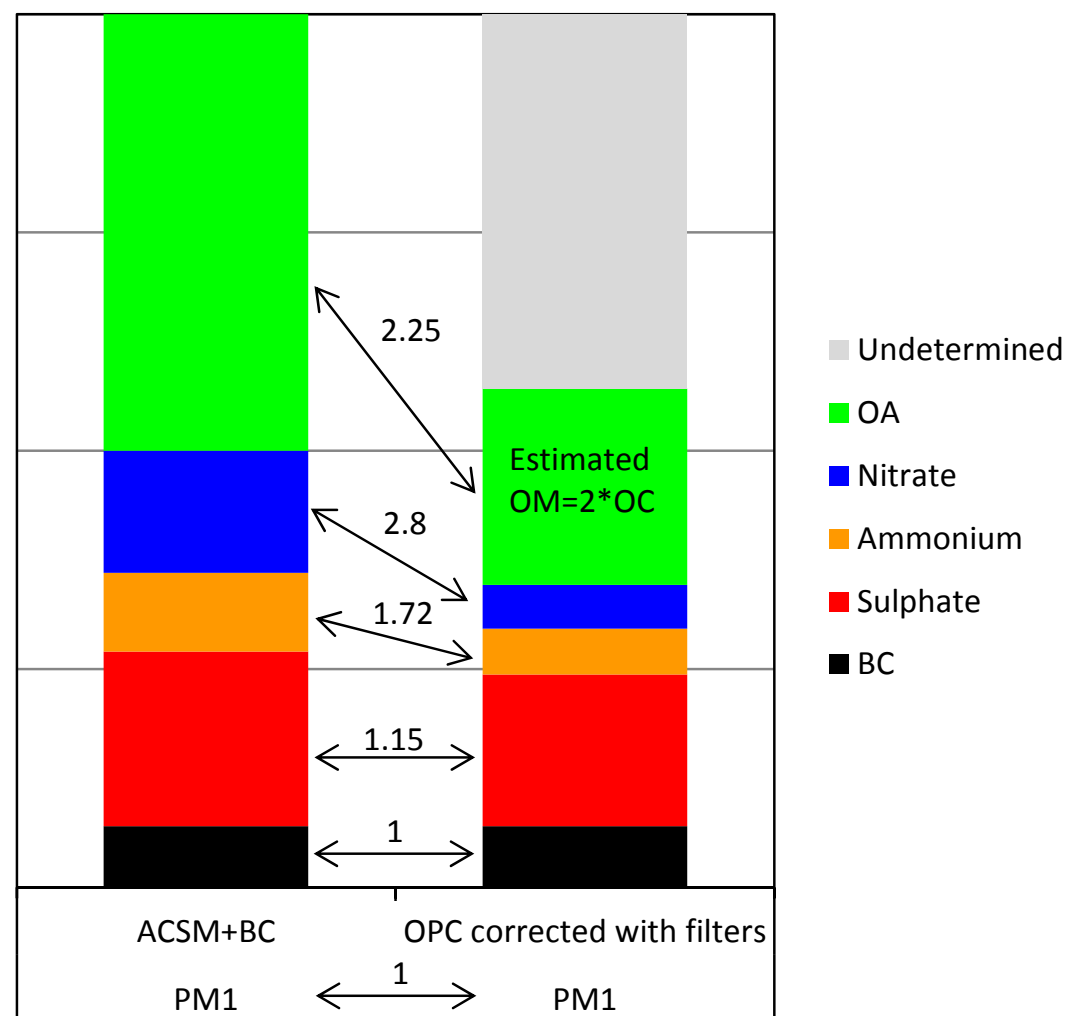

Figure S5. Schematic comparison of ACSM components $+B C$ concentrations vs $P M_{1}$ concentrations from OPC corrected with gravimetric determinations. The numbers indicate the slopes found for experimental data for Montseny during June 2012 to July 2013. The 2.25 corresponds to the slope of OA (ACSM) vs OM estimated from OC (filters) as $2 * O C$. 


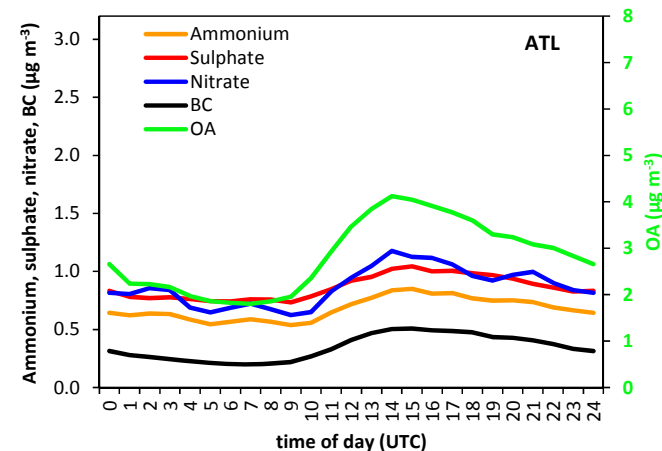

a)

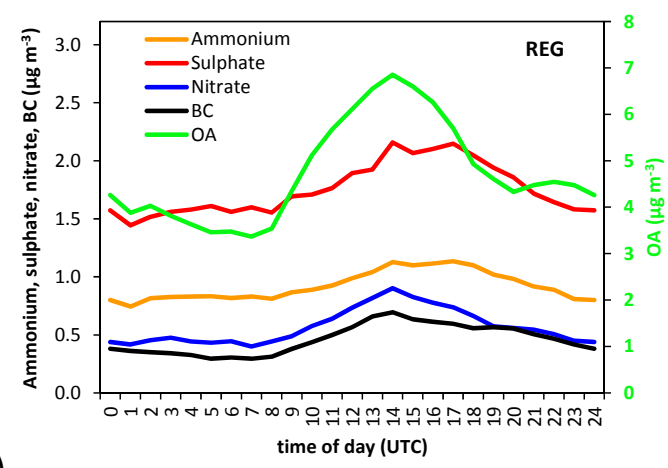

c)

Figure S6. Average daily pattern for (a) Atlantic advections (ATL), (b) North African episodes (NAF), (c) regional episodes (REG), and (d) Winter Anticyclonic episodes (WAE). Note that OA is plotted in the right axis.

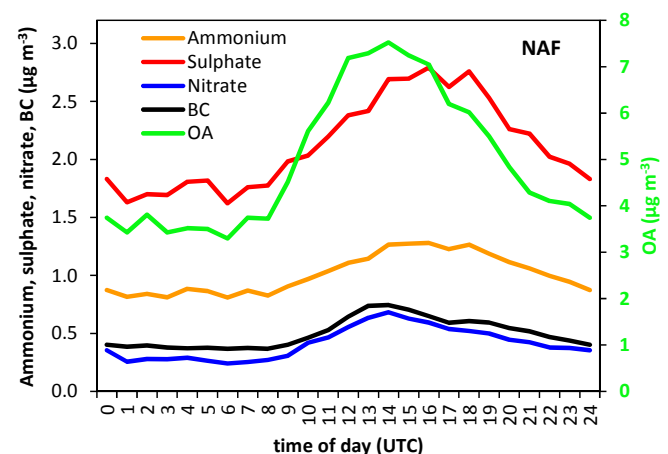

b)

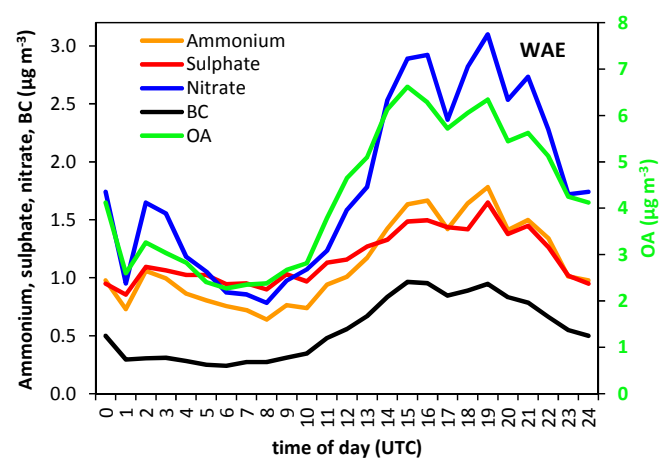

d) 
NAAPS Total Optical Depth for 12:00Z 23 Jut 2012

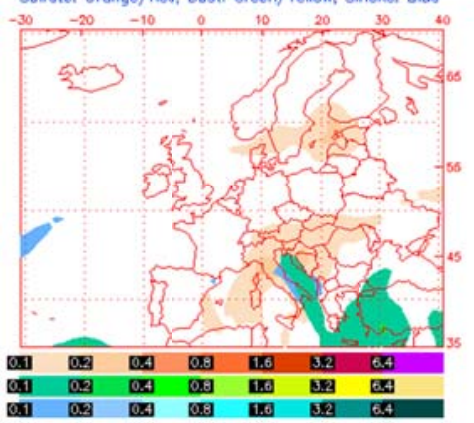

Dust Surface Concontration (ug/m*3$$
\text { for } 12.002 .25 \text { cond }
$$

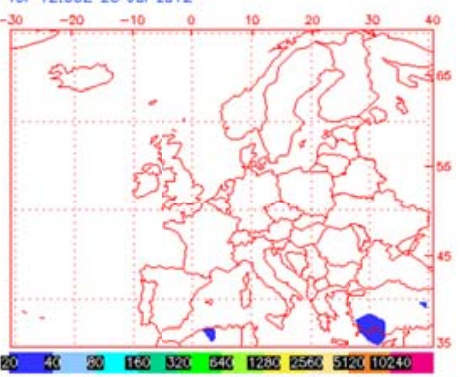

a)

NAAPS Total Optical Depth for 12:00Z 24 Jul 2012

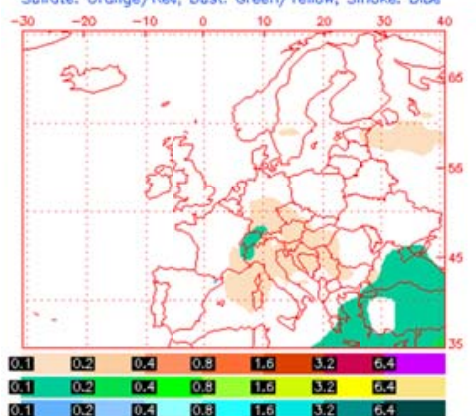

Dust Surface Concentrotion (ug/mw3)

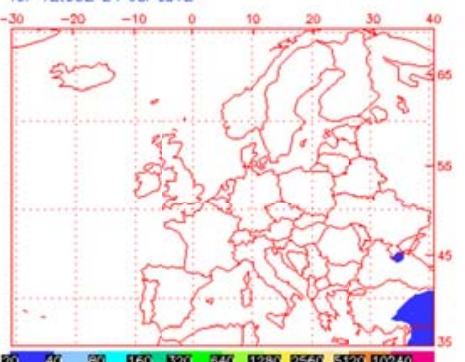

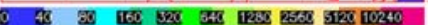

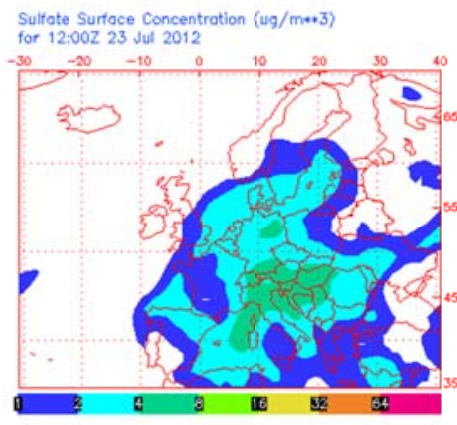

Smoke Surfoce Concentrotion ( $\mathrm{ug} / \mathrm{mm}=3$ )

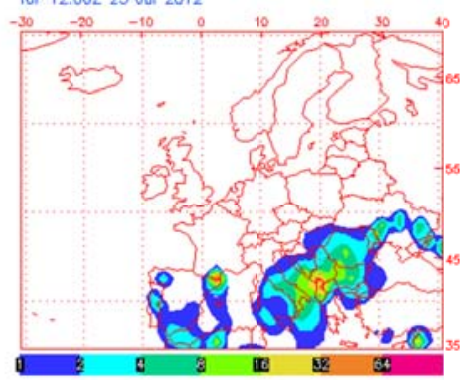

Sulfote Surfoce Concentrotion $(\mathrm{ug} / \mathrm{m} * \mathbf{3})$

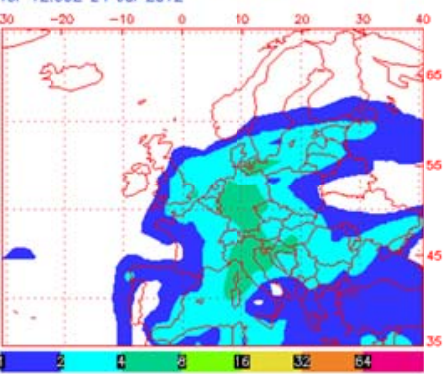

Smoke Surfoce Concentration (ug/mm3)

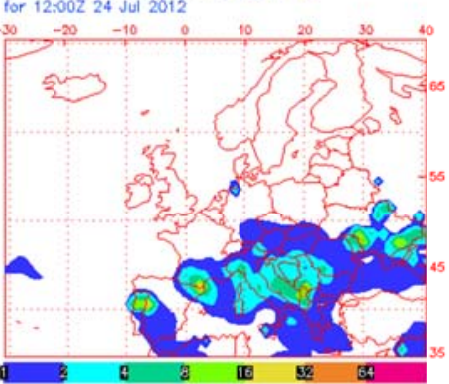

b) Tue sul $2421: 55: 342011$ UTC NRL/Monterey herosol Moseling 

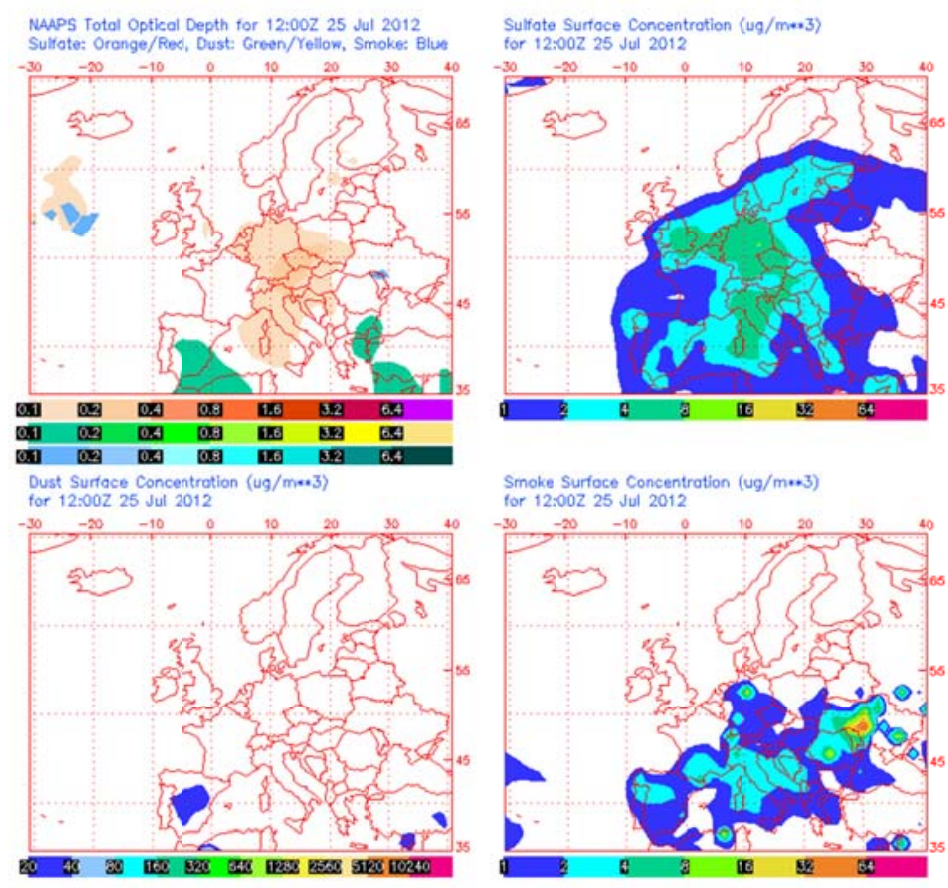

c)
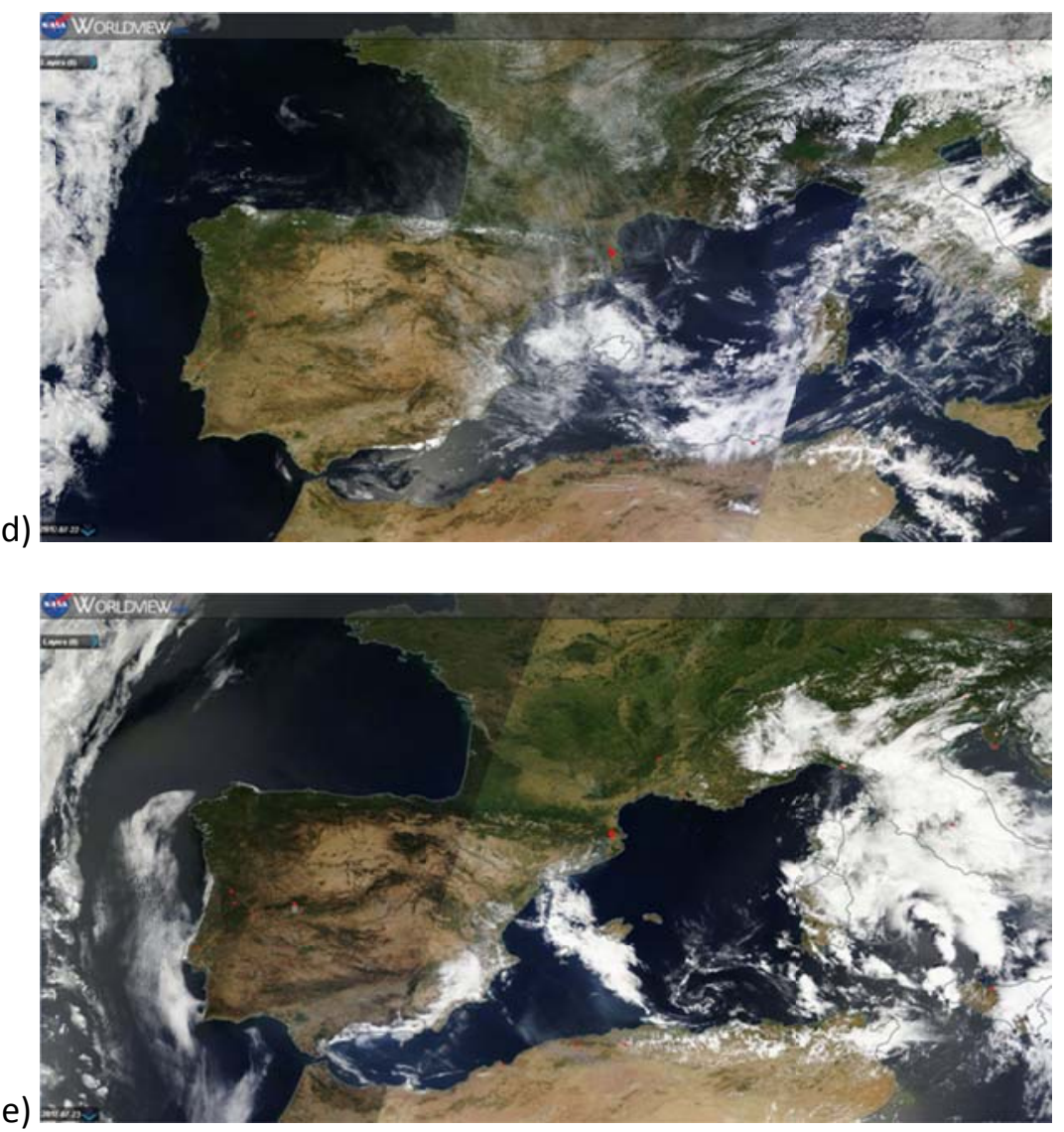

Figure S8. Total optical depth, sulphate surface concentration, dust surface concentration, and smoke surface concentration from the NAAPS model for 23, 24 and 25 July 2012 (wildfire event) (a-c), and satellite images from 22 and 23 July 2012 from The Earth Observing System Data and Information System (EOSDIS), NASA's Earth Science Data Systems Program (d, e). 

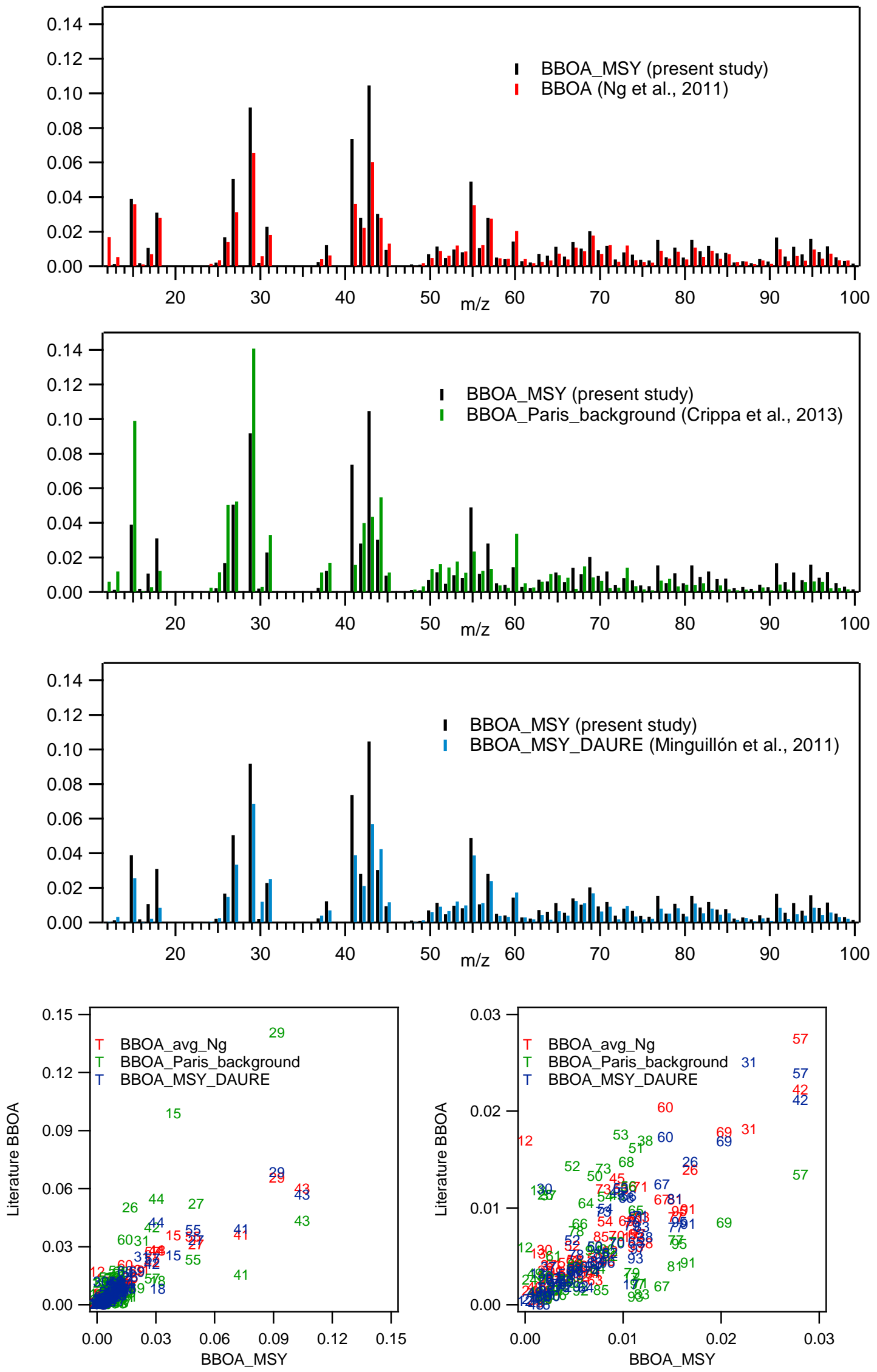

Figure S9. Comparison of the BBOA factor found for the wildfire episode (BBOA_MSY) with other BBOA profiles found in the literature (Minguillón et al., 2011;Ng et al., 2011;Crippa et al., 2013). The scatter plot on the right is a zoom for values from 0.00 to 0.03 . 


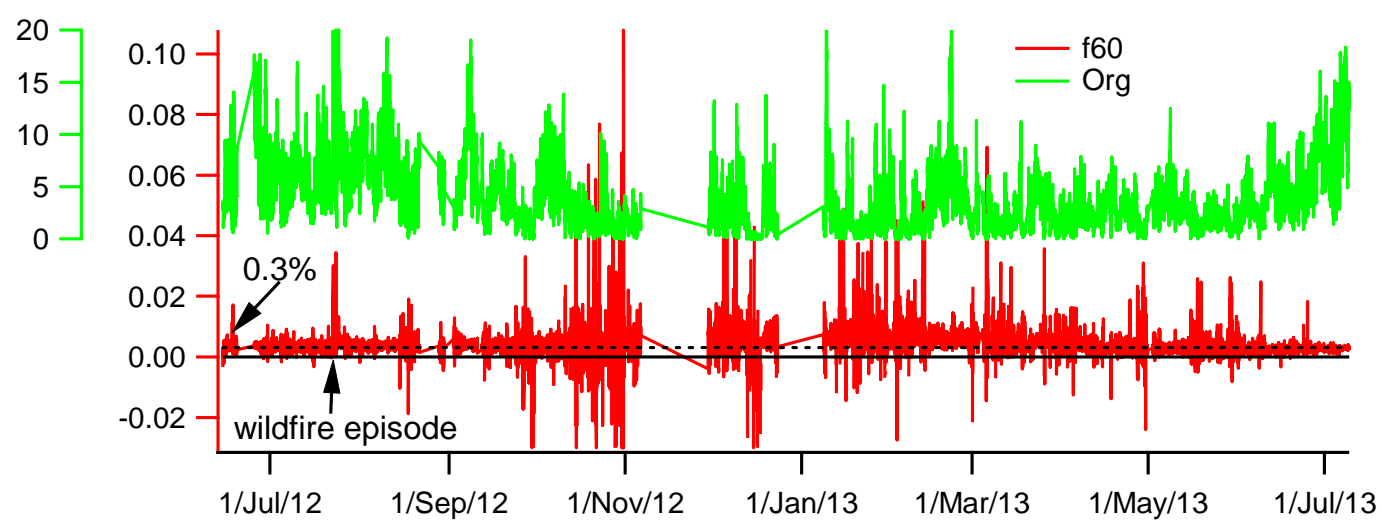

Figure S10. Time series of $\mathrm{f} 60$ (unitless) and OA concentration $\left(\mu \mathrm{g} \mathrm{m}^{-3}\right)$ throughout the study period at MSY. Dashed line corresponds to the $0.3 \%$ threshold for the $\mathrm{f} 60$ determined by Cubison et al. (2011).
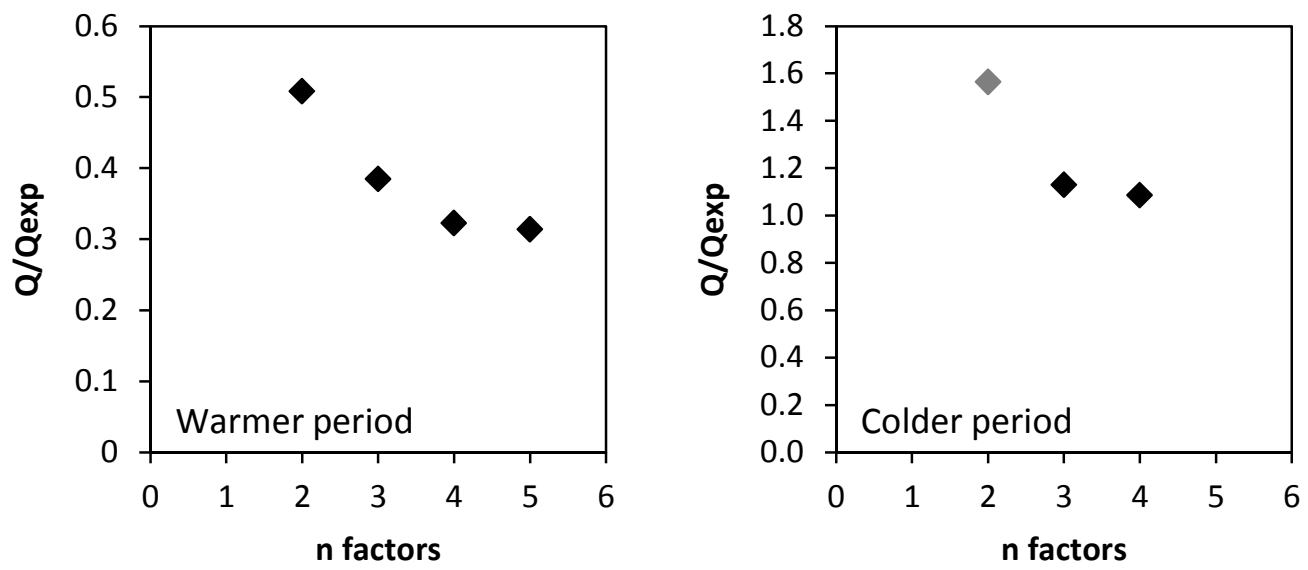

Figure S11. Q/Qexp vs number of factors for the warmer and the colder periods. The grey dot in the colder period corresponds to a solution with an a-value of 0.2 for the BBOA factor, given that there was no convergence with an a-value of 0.1 for the 2 -factors solution. 

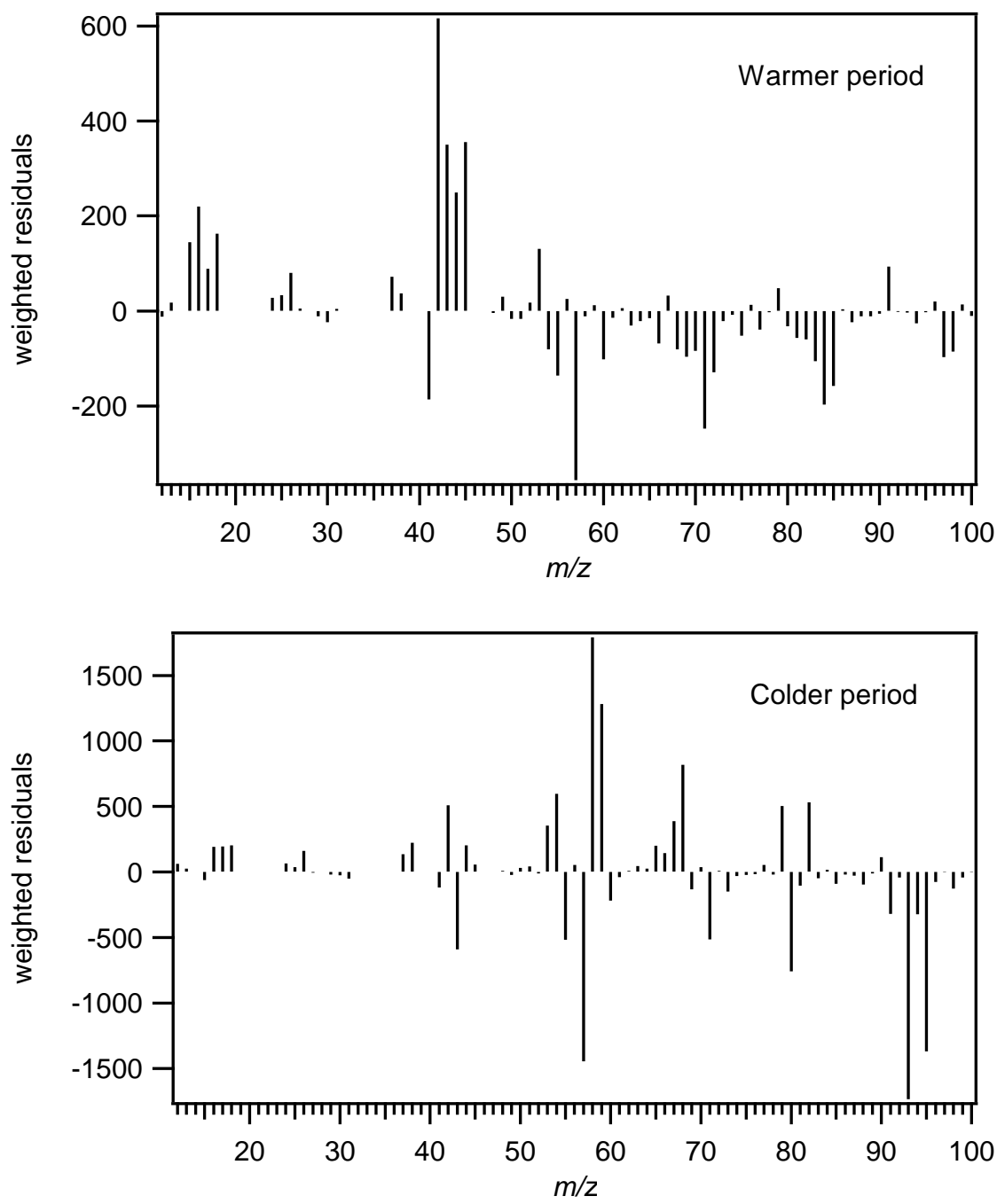

Figure S12. Weighted residuals vs $m / z$ for the warmer and the colder periods. 

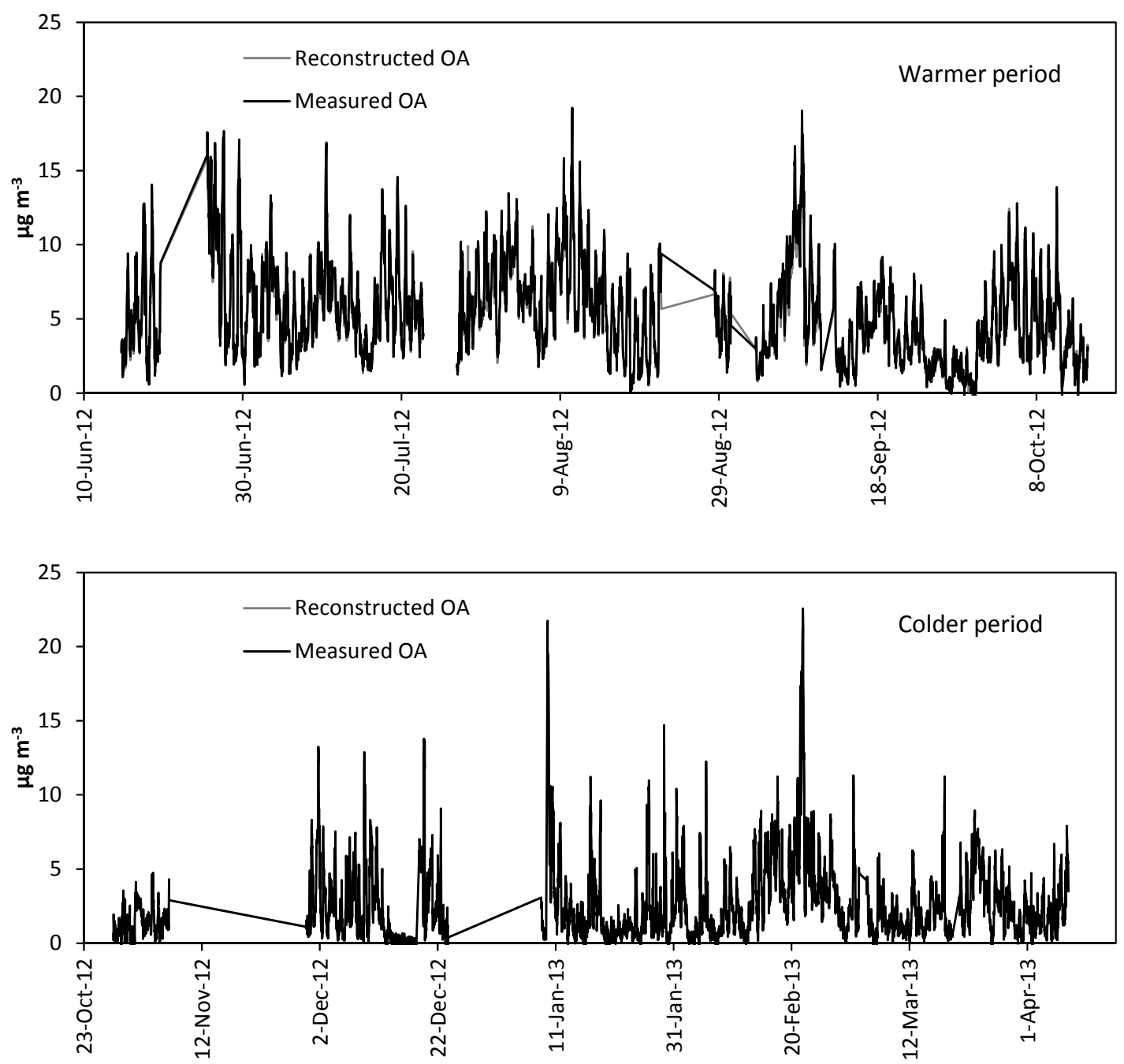

Figure S13. Time series of the measured and reconstructed OA concentrations for the warmer and the colder periods. 

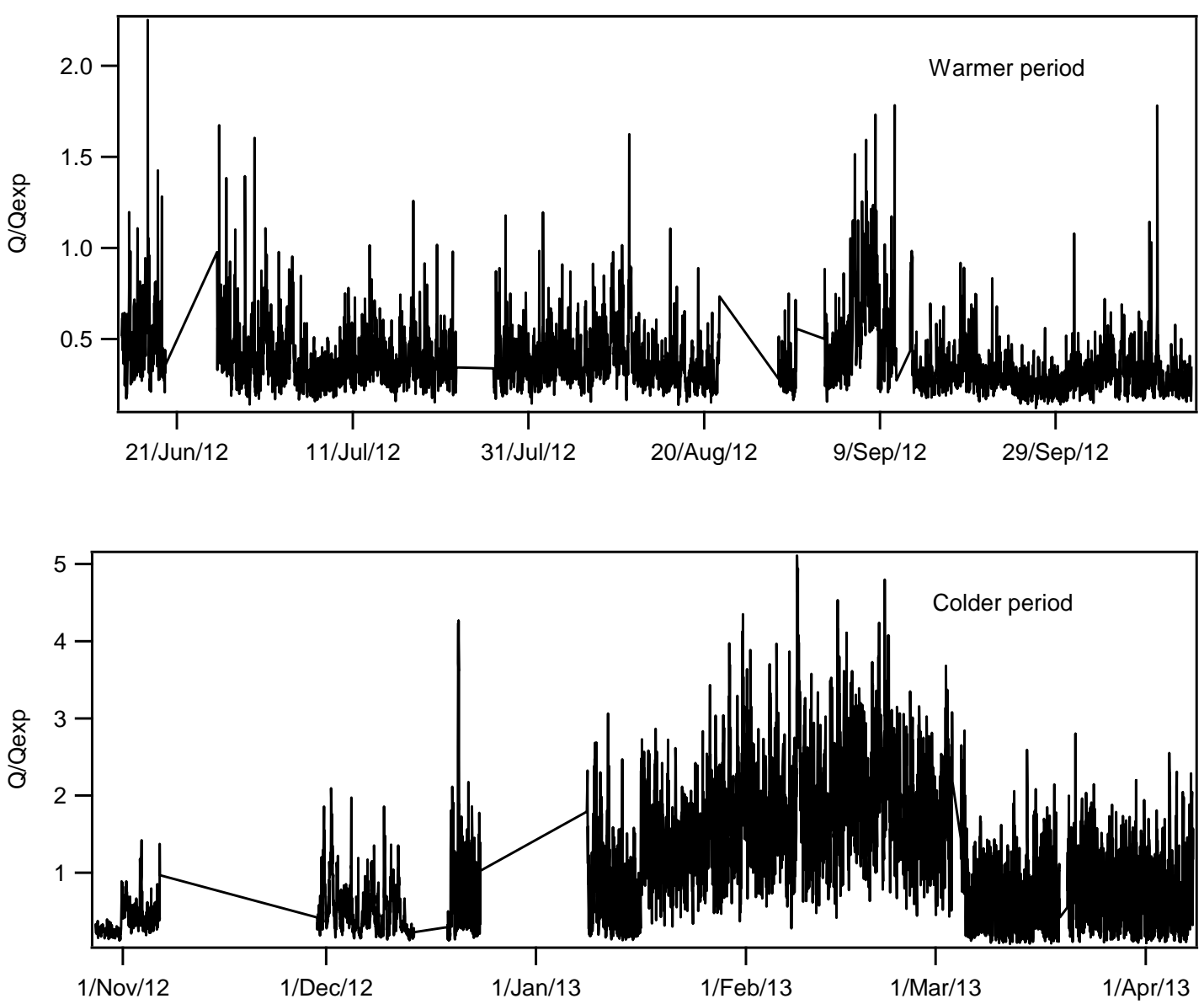

Figure S14. Time series of Q/Qexp for the warmer and the colder periods. 

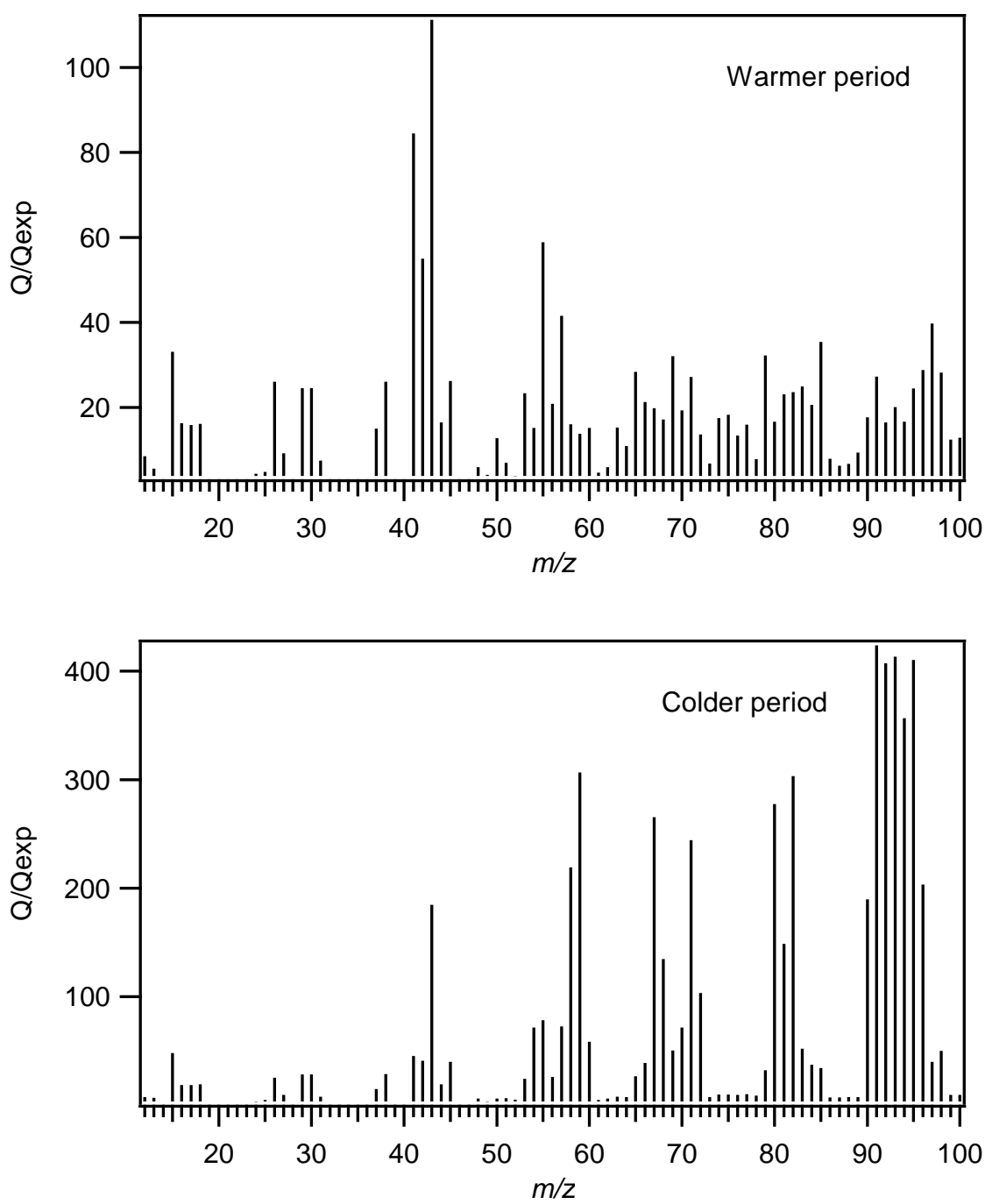

Figure S15. Q/Qexp vs $m / z$ for the warmer and the colder periods. 

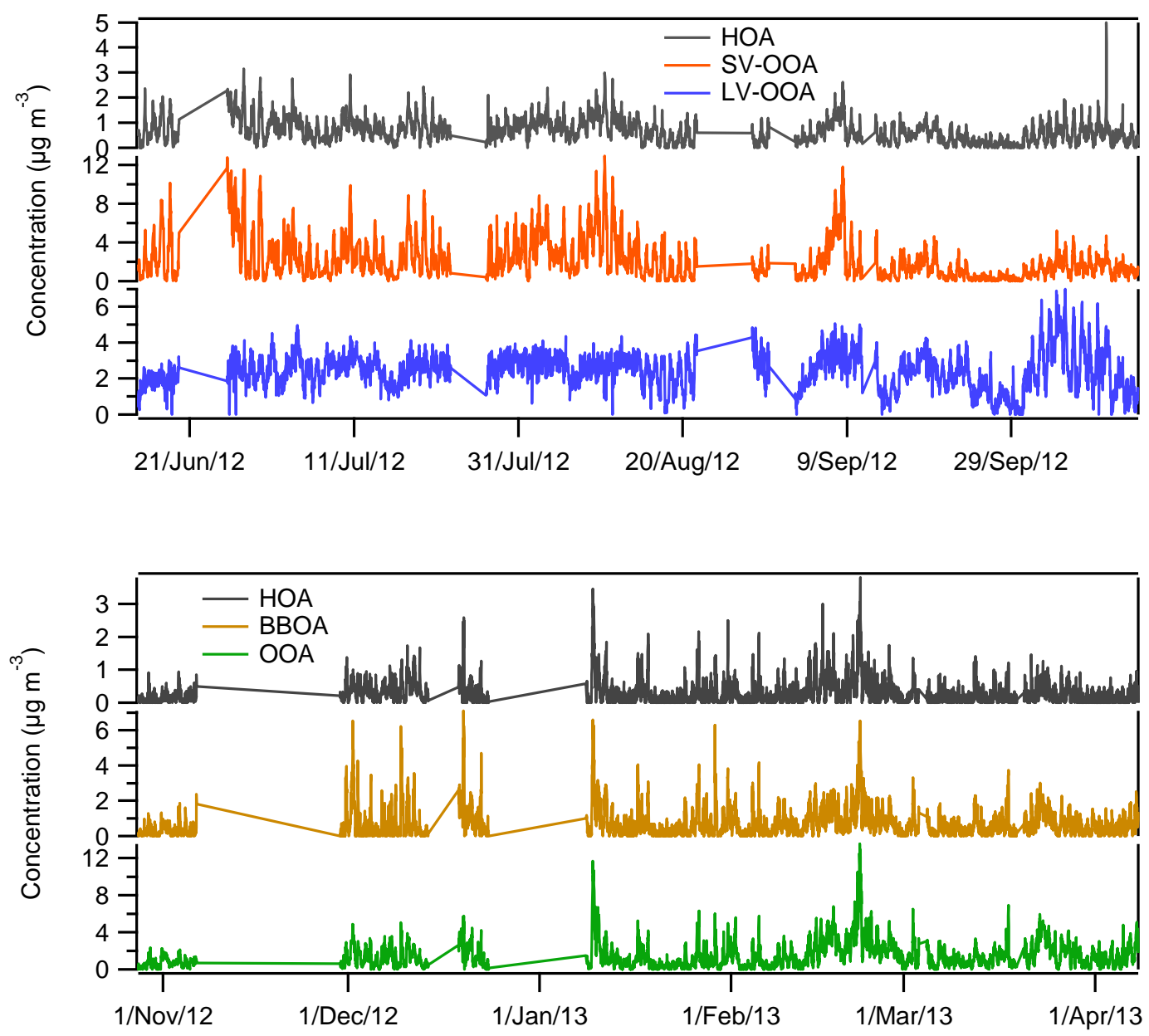

Figure S16. Time series of the OA sources in the warmer (top) and the colder (bottom) periods. 


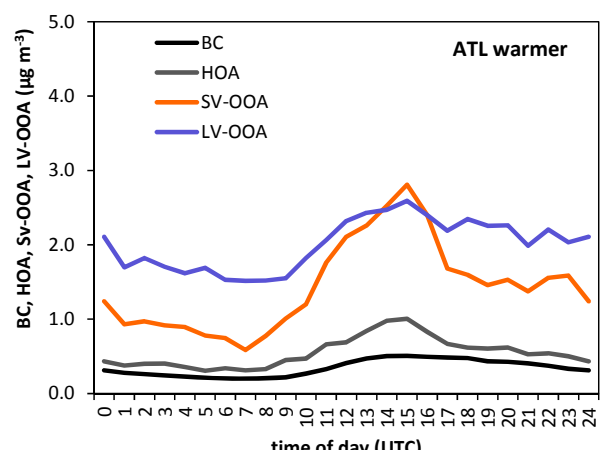

a)

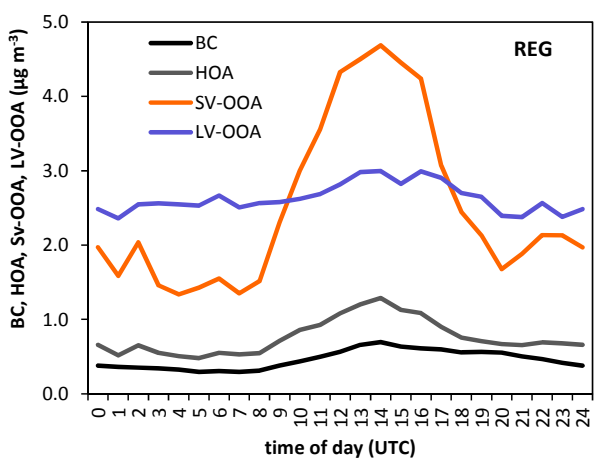

c)

Figure S17. Average daily pattern for Atlantic advections (ATL), for the warmer and the colder periods, regional episodes (REG) (only warmer period), and Winter Anticyclonic episodes (WAE) (only colder period).

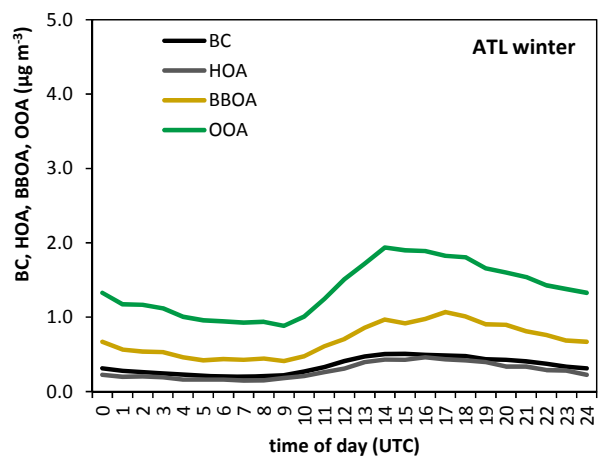

b)

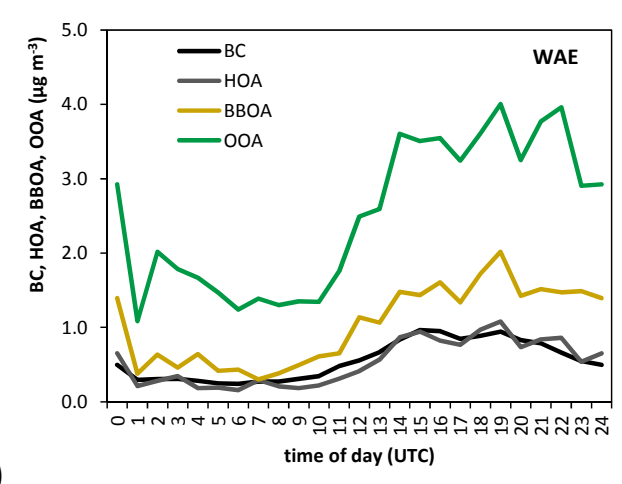

d) 
Table S1. Squared Pearson correlation coefficients between OA sources/types and BC, sulphate, nitrate and ammonium for the warmer and the colder periods.

\begin{tabular}{|c|c|c|c|c|c|}
\hline \multicolumn{2}{|c|}{$\mathbf{R}^{2}$} & BC & SO4 & NO3 & NH4 \\
\hline \multirow{3}{*}{$\begin{array}{c}\text { Warmer } \\
\text { period }\end{array}$} & HOA & 0.51 & 0.16 & 0.23 & 0.16 \\
\cline { 2 - 6 } & SV-OOA & 0.32 & 0.17 & 0.16 & 0.13 \\
\cline { 2 - 6 } & LV-OOA & 0.45 & 0.34 & 0.27 & 0.43 \\
\hline \multirow{2}{*}{$\begin{array}{c}\text { Colder } \\
\text { period }\end{array}$} & HOA & 0.70 & 0.20 & 0.53 & 0.49 \\
\cline { 2 - 6 } & BBOA & 0.66 & 0.21 & 0.49 & 0.47 \\
\cline { 2 - 6 } & OOA & 0.71 & 0.49 & 0.73 & 0.79 \\
\hline
\end{tabular}

\section{REFERENCES}

Crippa, M., DeCarlo, P. F., Slowik, J. G., Mohr, C., Heringa, M. F., Chirico, R., Poulain, L., Freutel, F., Sciare, J., Cozic, J., Di Marco, C. F., Elsasser, M., Nicolas, J. B., Marchand, N., Abidi, E., Wiedensohler, A., Drewnick, F., Schneider, J., Borrmann, S., Nemitz, E., Zimmermann, R., Jaffrezo, J. L., Prévôt, A. S. H., and Baltensperger, U.: Wintertime aerosol chemical composition and source apportionment of the organic fraction in the metropolitan area of Paris, Atmos. Chem. Phys., 13, 961-981, 10.5194/acp-13-961-2013, 2013.

Cubison, M. J., Ortega, A. M., Hayes, P. L., Farmer, D. K., Day, D., Lechner, M. J., Brune, W. H., Apel, E., Diskin, G. S., Fisher, J. A., Fuelberg, H. E., Hecobian, A., Knapp, D. J., Mikoviny, T., Riemer, D., Sachse, G. W., Sessions, W., Weber, R. J., Weinheimer, A. J., Wisthaler, A., and Jimenez, J. L.: Effects of aging on organic aerosol from open biomass burning smoke in aircraft and laboratory studies, Atmos. Chem. Phys., 11, 12049-12064, 2011.

Middlebrook, A. M., Bahreini, R., Jimenez, J. L., and Canagaratna, M. R.: Evaluation of composition-dependent collection efficiencies for the Aerodyne aerosol mass spectrometer using field data, Aerosol Sci. Technol., 46, 258-271, 2012.

Minguillón, M. C., Perron, N., Querol, X., Szidat, S., Fahrni, S. M., Alastuey, A., Jimenez, J. L., Mohr, C., Ortega, A. M., Day, D. A., Lanz, V. A., Wacker, L., Reche, C., Cusack, M., Amato, F., Kiss, G., Hoffer, A., Decesari, S., Moretti, F., Hillamo, R., Teinilä, K., Seco, R., Peñuelas, J., Metzger, A., Schallhart, S., Müller, M., Hansel, A., Burkhart, J. F., Baltensperger, U., and Prévôt, A. S. H.: Fossil versus contemporary sources of fine elemental and organic carbonaceous particulate matter during the DAURE campaign in Northeast Spain, Atmos. Chem. Phys., 11, 12067-12084, 10.5194/acp-11-12067-2011, 2011.

Ng, N. L., Canagaratna, M. R., Jimenez, J. L., Zhang, Q., Ulbrich, I. M., and Worsnop, D. R.: Realtime methods for estimating organic component mass concentrations from aerosol mass spectrometer data, Environ. Sci. Technol., 45, 910-916, 2011. 